\title{
タイ，ベトナムおよび日本産魚奨油の化学的性状の比較
}

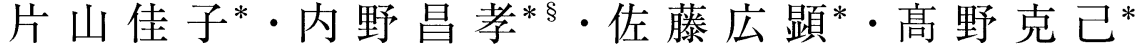 \\ * 東京農業大学応用生物科学部応用化学科
}

\section{Chemical Property on Fish Sauce Produced in Thailand, Vietnam, and Japan}

\author{
Katayama Yoshiko*, Uchino Masataka*§, Sato Hiroaki* and Takano Katsumi* \\ * Department of Applied Biology and Chemistry, Faculty of Applied Bio-Science, Tokyo University of Agriculture, \\ 1-1-1, Sakuragaoka, Setagaya-ku, Tokyo 156-8502
}

The chemical properties of fish sauces $(n=66)$ collected from Thailand, Vietnam and Japan were determined. As results, the salt content, $\mathrm{pH}$, for mol nitrogen content, free amino acid content and total nitrogen content ranges of these sauces were $14 \sim 28 \%, 5 \sim 8,0.23 \sim 4.22 \mathrm{~g} / 100 \mathrm{~m} \ell, 1.75 \sim 22.51$ $\mathrm{g} / 100 \mathrm{~m} \ell$ and $1 \sim 6 \mathrm{~g} / 100 \mathrm{~m} \ell$, respectively. These ranges were wide compared with previous reports. In addition, fish sauces with a high total nitrogen content had a high peptide nitrogen content. Note that peptides are related to body function. The average of peptides in all the fish sauces was $32 \%$ of total nitrogen content. The Thai and Vietnamese sauces showed higher peptide nitrogen contents than the Japanese sauces. Note that fish sauces in Thailand and Vietnam, which are in the subtropical zone from the tropical zone, are ripened at higher temperatures than those in Japan, which is in the temperate zone. Therefore, it was presumed that the decomposition of fish meat protein by protease was faster in Thailand and Vietnam than in Japan. Moreover, the glutamic acid contents at $12 \%$ on average were higher than the total free amino acid contents. However, there were some samples with glutamic acid contents of $20 \sim 30 \%$, which were higher than the glutamic acid content of fish meat protein. These samples were considered to have been supplemented with glutamic acid.

(Received Jun. 4, 2008 ; Accepted Aug. 25, 2008)

Key words: fish sause, soy sause, chemical property, peptide, amino acid 魚滰油, 酱油, 化学的性状, ペプチド, アミノ酸

魚滰油は魚に食塩を加え, 腐敗を防止しながら魚肉夕 ンパク質をペプチドやアミノ酸にまで分解させた発酵食 品である。日本から東南アジアの沿海地域で製造され, 東南アジアでは日本の奨油と同様, 日常欠かすことので きない調味料である。

酱油が食塩濃度16〜18\%, pH 4.7〜4.9, 全窒素1. 5 ～1.6に対し, 魚奨油では食塩濃度20〜25\%, pH 5.7〜

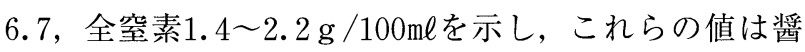
油に比べ幅がある1)。原料の魚や製造法が多様なことが これらの值に大きな違いがあると考えられる文 。また， 魚奨油は滰油に比べぺプチド含量が高く ${ }^{6)}$, 苦味, 塩味 および酸味に対する緩和作用が7), 魚奨油の持つコク味 や深味に関与しているといわれている1”。

近年, 大豆タンパク質や乳タンパク質などの分解物か らコレステロール值の低下や血圧上昇抑制などの作用を 示すぺプチドが見いだされている ${ }^{8,9)}$ 。魚槒油からもア
ンジオテンシン変換酵素阻害活性 ${ }^{10)}{ }^{11)}$ や抗酸化性 ${ }^{12)}$ を示 すぺプチドが報告されているが，その報告が少なく試料 数が限定されているなど, 機能性ペプチドの存在とその 作用について十分に検証されていない。

私たちは魚奨油中のペプチドの生成機序ならびにペプ チドの機能を明らかにすることを目的に研究を進めてい る。

本報では, 日本産とベトナム産, 夕イ産の魚奨油66点 を用いて魚槒油の化学的性状を比較検討した。

\section{試料および実験方法}

\section{1. 試料}

試料には夕イ産 8 種, ベトナム産 29 種および日本産 29 種の計 66 種の魚酱油を用いた。

\section{2. 食塩濃度およびpHの測定}

食塩濃度はソルトメーター（コンパクト塩分計C-121,

* ₹156-8502 東京都世田谷区桜丘 1-1-1

$\S$ 連絡先 (Corresponding author) E-mail : muchino@nodai.ac.jp 
堀場社製)，pHはpHメーター（M-12，堀場社製）で測 定した。

\section{3. 全窒素, ホルモール態窒素および遊離アミノ酸分析} 全窒素量はNCコーダー（SUMIGRAPH NC-90A, 住 化分析センター社製）を用い，ホルモール態窒素量は滰 油分析法 ${ }^{13)}$ に従い測定した。

遊離アミノ酸分析 ${ }^{14)}$ はHPLC (LC-10AD $D_{\mathrm{VP}}$, 島津製作 所製）にて行った。試料を純水にて50倍希釈し, 遠心濾 過用マイクロチューブ（日本ミリポア工業社製, 分画分 子量 10,000$)$ を用いて遠心分離 $(2,500 \times \mathrm{g}, 10$ 分間 $)$ を行い, 得られた濾液を濃縮遠心機にて完全乾固し, NBD-Fにてプレラベルし分析に供した。

総遊離アミノ酸量を $6.25 て ゙$ 除してアミノ態窒素量を求 め, ペプチド態窒素量（P-N）は下式により算出した。

$\mathrm{P}-\mathrm{N}(\mathrm{g} / 100 \mathrm{~m} \ell)=\mathrm{T}-\mathrm{N}-\mathrm{A}-\mathrm{N}$

( $\mathrm{T}-\mathrm{N}$ : 全窒素量, A-N : アミノ態窒素量)

\section{結果および考察}

食塩濃度, $\mathrm{pH}$, ホルモール態窒素量, 遊離アミノ酸 量, アミノ態窒素量, 全窒素量およびペプチド態窒素量 をTable 1 に示した。

\section{1. 食塩濃度およびpH}

夕イ産魚滰油の食塩濃度は28および26\%がそれぞれ 2 点, $25 \%$ が 3 点, $24 \%$ が 1 点, ベトナム産では $23 \%$ 最 も多く 9 点, 次いで $22 \%$ が 7 点, $25 \%$ が 4 点, $19 \%$ が 3 点， $21 \%$ と $24 \%$ が 2 点，17\%および $14 \%$ それれぞれ 1 点, 日本産では $25 \%$ が 15 点, $19 \%$ が 5 点, $26 \%$ が 3 点, $23 \%$ および $22 \%$ ぞそぞれ 2 点，28\%および $15 \%$ お゙ 1 点であ つた。既報では, 夕イ産23.5 24.7\% $\%^{15)}$, ベトナム産 $20.3 \sim 25.3 \%{ }^{1)}$, 日本産 $14.7 \sim 29.0 \%{ }^{15)}$ であり, 今回の 試験結果でも夕イ産は既報と同様に高く $24 \sim 28 \%$ あっ たが，ベトナム産は14〜25\%と報告よりも幅広く, 日本 産は15〜28\%と幅のあるものの既報の範囲内であった。 川㟝 ${ }^{21}$ は市販魚奨油では発酵原液そのままではなく, 塩 水で薄めた製品や加糖した製品があることを報告し, 今 回の試料にもそのような処理を行ったものが含まれてい たものと考える。

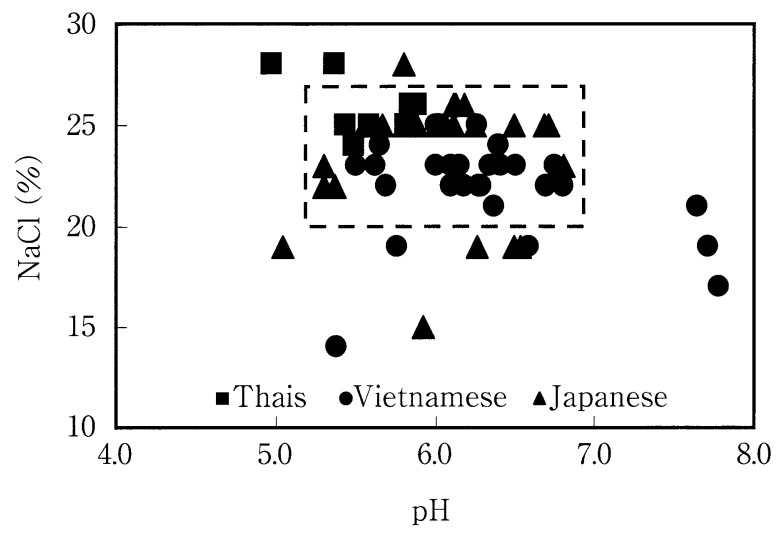

Fig. 1 Distribution of $\mathrm{NaCl}$ and $\mathrm{pH}$ in fish sauce
タイ産魚滰油のpHは5.8および5.4が 2 点，5.9，5.6， 5.5 および5.0がそれぞれ 1 点，ベトナム産 6.0 - 6.8が 20 点, $5.4 \sim 5.8$ が 6 点, $7.7 \sim 7.8$ が 3 点, 日本産 $6.0 \sim 6.8$ が15点，5.1〜 5.9が14点であった。魚酱油のpHについ て既報では, 夕イ産5.1〜 5. $6^{15)}$, ベトナム産5.68〜 $6.72^{1)}$, 日本産4.8 $5.7^{15)}$ である。今回の試験結果でも 夕イ産の5.0〜 5. 9は既報とほぼ同様であったが，ベトナ 厶産は5.4〜 7.8とやや高く, 日本産では5.1〜6.8であ り，5.0以下を示す試料はなかった。

今回分析した 66 点中の食塩濃度は既報の範囲であった が, $\mathrm{pH}$ は 8 付近を示す試料が 3 点あり，従来の報告よ り，そのpHは範囲が広かった。また，ベトナム産の 5 点は食塩濃度 $20 \%$ 未満であり，これらは東南アジアの製 品としては食塩濃度が低かった。

なお, 食塩濃度と $\mathrm{pH} は$ は相関はみられなかった。魚 奨油のpHは発酵中に生じる有機酸量に大きく影響され る。高い食塩濃度では, 微生物の増殖が抑制されるが, 食塩濃度と $\mathrm{pH}$ に相関性がみられなかったことから, 各 試料の緩衝能, 原料魚種, 発酵温度ならびに微生物種な どのさまざまな要因が絡んでいるものと思われる备)。べ トナム産V25およびV28のpHはそれぞれ7.7と7.8と高く， 食塩濃度が19および17\%と低いことから，ほかの魚奨油 に比ベタンパク質の分解が進みアミンやアンモニアの生 成の影響が推察され ${ }^{1)}$ ，ほかの魚奨油と菌叢に差異が考 えられた。

\section{2. 全窒素量}

全窒素量の平均值は $2.11 \mathrm{~g}$ で奨油の約 $1.50 \mathrm{~g}$ に比べ高 い值であった。最高值はべトナム産V12の $6.11 \mathrm{~g}$, 最低 值は日本産J 1 の $0.35 \mathrm{~g}$ であり, 66点中48点が奨油の值 より高い数值であった。国別の平均值を比較するとべト ナム産が $2.58 \mathrm{~g}$ でもっとも高く, 夕イ産の $1.83 \mathrm{~g}$, 日本 産がやや低めで $1.71 \mathrm{~g}$ であった。夕イでは全窒素量 $1 \%$ 以下の製品は, 低級品とされる ${ }^{17)}$ 。道畠ら ${ }^{18)}$ はイシルの 熟成期間を短縮するため, 加温することにより魚自身の 自己消化酵素の作用を高め, イワシイシルでは $40^{\circ} \mathrm{C} て ゙$ 全 窒素量は最大値 $2.44 \mathrm{~g} / 100 \mathrm{~m} \ell$ 示したと述べている。こ のことは，東南アジアに位置するタイやべトナムでは日 本より気温が高く, 熟成中のプロテアーゼの作用が増大 し, 魚肉タンパク質の分解が進み, 全窒素量が日本産魚 奨油より高い值を示したものと推察される。

また, 川浐 ${ }^{21}$ は鍻を用いて加水なしで魚肉を発酵させ た場合, 通常よりタンパク質の分解率が高くなり, 全窒 素量が $3 \%$ 以になることを報告している。阿部5はべ トナム産魚奨油では窒素含量が $3 \%$ 超えるものもいく つか認められたと指摘しており，V12はかなり分解が進 んだものと考えられ，その製造方法に興味がもたれる。

\section{3.アミノ態およびペプチド態窒素量}

全窒素やアミノ態窒素が高いほど嗜好的に好ましいと されている。アミノ態窒素量の平均值は $1.39 \mathrm{~g}$ であり, 国別平均值を比較してもべトナム産が $1.53 \mathrm{~g}$, 夕イ産が 
Table 1 Chemical properties of fish sauce

\begin{tabular}{|c|c|c|c|c|c|c|c|}
\hline $\begin{array}{c}\text { Sample } \\
\text { No. }\end{array}$ & $\begin{array}{c}\mathrm{NaCl} \\
(\%)\end{array}$ & $\mathrm{pH}$ & $\begin{array}{c}\text { Formol } \\
\text { nitrogen } \\
(\mathrm{g} / 100 \mathrm{~m} \ell)\end{array}$ & $\begin{array}{c}\text { Amino } \\
\text { acid } \\
(\mathrm{g} / 100 \mathrm{~m} \ell)\end{array}$ & $\begin{array}{c}\text { Amino } \\
\text { nitrogen } \\
(\mathrm{g} / 100 \mathrm{~m} \ell)\end{array}$ & $\begin{array}{c}\text { Total } \\
\text { nitrogen } \\
(\mathrm{g} / 100 \mathrm{~m} \ell)\end{array}$ & $\begin{array}{c}\text { Peptide } \\
\text { nitrogen } \\
(\mathrm{g} / 100 \mathrm{~m} \ell)\end{array}$ \\
\hline T 1 & 28 & 5.4 & 0.74 & 5.06 & 0.81 & 0.84 & 0.03 \\
\hline $\mathrm{T} 2$ & 28 & 5.0 & 0.77 & 5.15 & 0.82 & 1.07 & 0.25 \\
\hline $\mathrm{T} 3$ & 26 & 5.9 & 1. 67 & 9.01 & 1.44 & 2.22 & 0.78 \\
\hline $\mathrm{T} 4$ & 26 & 5.8 & 1.40 & 7.53 & 1.20 & 1.70 & 0.50 \\
\hline $\mathrm{T} 5$ & 25 & 5.8 & 2.12 & 12.96 & 2.07 & 3.03 & 0.96 \\
\hline T 6 & 25 & 5.6 & 1.24 & 8.80 & 1.41 & 1.78 & 0.37 \\
\hline T 7 & 25 & 5.4 & 1. 61 & 9.44 & 1.51 & 2.18 & 0.67 \\
\hline T 8 & 24 & 5.5 & 1.06 & 8.25 & 1.32 & 1.81 & 0.49 \\
\hline Mean & 25.9 & 5.55 & 1.33 & 8.28 & 1.32 & 1.83 & 0.50 \\
\hline V 1 & 25 & 6.3 & 1.74 & 9.23 & 1.48 & 2.20 & 0.72 \\
\hline V 2 & 25 & 6.0 & 2.58 & 14.72 & 2.36 & 3.80 & 1.44 \\
\hline V 3 & 25 & 6.0 & 2.41 & 14.54 & 2.33 & 3.38 & 1.05 \\
\hline V 4 & 25 & 6.0 & 2.19 & 12.48 & 2.00 & 2.81 & 0.81 \\
\hline V 5 & 24 & 6.4 & 1.72 & 8.70 & 1.39 & 2.08 & 0.69 \\
\hline V 6 & 24 & 5.7 & 2.12 & 8.53 & 1. 36 & 3.63 & 2.27 \\
\hline V 7 & 23 & 6.8 & 2.59 & 12.88 & 2.06 & 3.39 & 1.33 \\
\hline V 8 & 23 & 6.5 & 2.33 & 10.82 & 1.73 & 3.28 & 1.55 \\
\hline V 9 & 23 & 6.4 & 2.01 & 9.24 & 1.48 & 2.74 & 1.26 \\
\hline V 10 & 23 & 6.4 & 1.74 & 9.40 & 1.50 & 2.23 & 0.73 \\
\hline V 11 & 23 & 6.2 & 1.90 & 8.38 & 1.34 & 2.60 & 1.26 \\
\hline V 12 & 23 & 6.1 & 4.22 & 22.51 & 3.60 & 6.11 & 2.51 \\
\hline V 13 & 23 & 6.0 & - & 4.49 & 0.72 & 1.20 & 0.48 \\
\hline V 14 & 23 & 5.6 & 2.17 & 13.23 & 2.12 & 3.00 & 0.88 \\
\hline $\mathrm{V} 15$ & 23 & 5.5 & 2.48 & 14.76 & 2.36 & 3.61 & 1.25 \\
\hline V 16 & 22 & 6.8 & 2.41 & 10.48 & 1.68 & 3.22 & 1.54 \\
\hline V 17 & 22 & 6.7 & 2.53 & 10.83 & 1.73 & 3.35 & 1.62 \\
\hline V 18 & 22 & 6.3 & 1. 66 & 8.98 & 1.44 & 2.10 & 0.66 \\
\hline V 19 & 22 & 6.3 & 1. 63 & 6.04 & 0.97 & 2.08 & 1.11 \\
\hline $\mathrm{V} 20$ & 22 & 6.2 & 2.12 & 10.25 & 1.64 & 3.43 & 1.79 \\
\hline V 21 & 22 & 6.1 & 1.10 & 5.89 & 0.94 & 1.24 & 0.30 \\
\hline V 22 & 22 & 5.7 & 1.23 & 6.55 & 1.05 & 1.45 & 0.40 \\
\hline $\mathrm{V} 23$ & 21 & 7.7 & - & 5. 36 & 0.86 & 1.37 & 0.51 \\
\hline V 24 & 21 & 6.4 & 1.78 & 6.92 & 1.11 & 2.20 & 1.09 \\
\hline $\mathrm{V} 25$ & 19 & 7.7 & - & 5.39 & 0.86 & 1.58 & 0.72 \\
\hline V 26 & 19 & 6.6 & - & 4.90 & 0.78 & 1.35 & 0.57 \\
\hline $\mathrm{V} 27$ & 19 & 5.8 & 1.81 & 9.64 & 1.54 & 2.37 & 0.83 \\
\hline $\mathrm{V} 28$ & 17 & 7.8 & 1.94 & 9.31 & 1.49 & 2.25 & 0.76 \\
\hline V 29 & 14 & 5.4 & - & 3.35 & 0.54 & 0.76 & 0.22 \\
\hline Mean & 22.0 & 6.31 & 2.10 & 9.58 & 1.53 & 2.58 & 1.05 \\
\hline $\mathrm{J} \quad 1$ & 28 & 5.8 & 0.23 & 1.75 & 0.28 & 0.35 & 0.07 \\
\hline J 2 & 26 & 6.2 & 0.80 & 7.21 & 1.15 & 1. 27 & 0.12 \\
\hline $\mathrm{J} 3$ & 26 & 6.1 & 0.85 & 7.53 & 1.20 & 1.39 & 0.19 \\
\hline $\mathrm{J} 4$ & 26 & 6.1 & 0.83 & 6.36 & 1.02 & 1. 36 & 0.34 \\
\hline $\mathrm{J} 5$ & 25 & 6.7 & 1.18 & 5.26 & 0.84 & 1.45 & 0.61 \\
\hline $\mathrm{J} \quad 6$ & 25 & 6.7 & 0.81 & 3.23 & 0.52 & 0.88 & 0.36 \\
\hline $\mathrm{J} \quad 7$ & 25 & 6.5 & 1.02 & 6.36 & 1.02 & 1.30 & 0.28 \\
\hline $\mathrm{J} \quad 8$ & 25 & 6.3 & 1.56 & 8.26 & 1.32 & 1.96 & 0.64 \\
\hline $\mathrm{J} \quad 9$ & 25 & 6.1 & 1.26 & 7.02 & 1.12 & 1.56 & 0.44 \\
\hline $\mathrm{J} 10$ & 25 & 6.1 & 1.20 & 6.93 & 1.11 & 1. 68 & 0.57 \\
\hline $\mathrm{J} 11$ & 25 & 6.0 & 0.95 & 5.79 & 0.93 & 1. 23 & 0.30 \\
\hline $\mathrm{J} 12$ & 25 & 6.0 & 0.95 & 5.77 & 0.92 & 1.25 & 0.33 \\
\hline $\mathrm{J} 13$ & 25 & 5.9 & 1.65 & 9.75 & 1.56 & 2.15 & 0.59 \\
\hline $\mathrm{J} 14$ & 25 & 5.9 & 1.64 & 10.11 & 1.62 & 2.30 & 0.68 \\
\hline $\mathrm{J} 15$ & 25 & 5.8 & 1.61 & 10.20 & 1.63 & 2.13 & 0.50 \\
\hline J 16 & 25 & 5.8 & 1.55 & 9.99 & 1.60 & 2.17 & 0.57 \\
\hline $\mathrm{J} 17$ & 25 & 5.8 & 1.54 & 9.47 & 1.52 & 2.15 & 0.63 \\
\hline $\mathrm{J} 18$ & 25 & 5.7 & 0.37 & 2.56 & 0.41 & 0.48 & 0.07 \\
\hline $\mathrm{J} 19$ & 25 & 5.6 & 1.29 & 8.01 & 1.28 & 1.69 & 0.41 \\
\hline $\mathrm{J} 20$ & 23 & 6.8 & 1.43 & 5.87 & 0.94 & 1.72 & 0.78 \\
\hline J 21 & 23 & 5.3 & 1.63 & 10.44 & 1.67 & 1.96 & 0.29 \\
\hline $\mathrm{J} 22$ & 22 & 5.4 & 1.53 & 10.06 & 1. 61 & 2.04 & 0.43 \\
\hline $\mathrm{J} 23$ & 22 & 5.3 & 1.49 & 9.58 & 1.53 & 1.80 & 0.27 \\
\hline $\mathrm{J} 24$ & 19 & 6.5 & 1.59 & 10.04 & 1. 61 & 2.04 & 0.43 \\
\hline $\mathrm{J} 25$ & 19 & 6.5 & 1.62 & 8.09 & 1. 24 & 2.02 & 0.78 \\
\hline $\mathrm{J} 26$ & 19 & 6.3 & 1.64 & 8.88 & 1.42 & 2.13 & 0.71 \\
\hline $\mathrm{J} 27$ & 19 & 5.1 & 2. 14 & 14.85 & 2.38 & 2.64 & 0.26 \\
\hline $\mathrm{J} 28$ & 19 & 5.1 & 2.10 & 14.29 & 2.29 & 2.82 & 0.53 \\
\hline $\mathrm{J} 29$ & 15 & 5.9 & 1.45 & 7.45 & 1.19 & 1.76 & 0.57 \\
\hline Mean & 23.5 & 5.97 & 1.31 & 7. 97 & 1.27 & 1. 71 & 0.44 \\
\hline
\end{tabular}

$\mathrm{T}$ : Made in Thailand $\mathrm{V}:$ Made in Vietnam $\mathrm{J}:$ Made in Japan - : Unmeasured

$1.32 \mathrm{~g}$ ，そして日本産が $1.27 \mathrm{~g}$ であり，全窒素量と同様 の傾向を示した。

ペプチド態窒素量の国別平均值は，ベトナム産が 1.05 $\mathrm{g}$ ともっとも高く, 次いで夕イ産の $0.50 \mathrm{~g}$, 日本産の 0.44 $\mathrm{g}$ の順であり，全窒素量およびアミノ態窒素量と同様の 傾向を示した。

全窒素に対するペプチド態窒素の割合を平均で国別に 見るとタイ産が $25 \%$ ，日本産が $26 \%$ そしてベトナム産が 


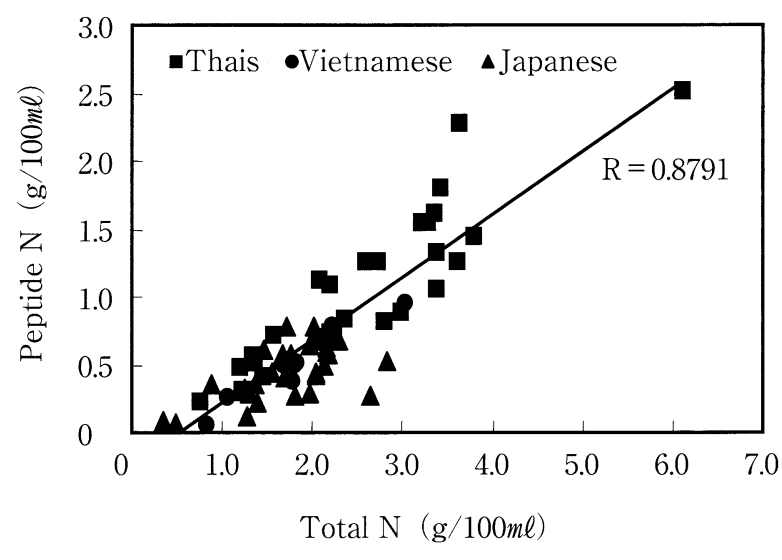

Fig. 2 Correlations between total nitrogen and peptide nitrogen of fish sauce

39\%と夕イ産と日本産に比べ，ベトナム産が高い値を示 した。ベトナム産V 6 の $63 \%$ が最も高く, 夕イ産のT 1 が $4 \%$ もっとも低く，平均で $32 \%$ あった。また，奨 油では10\%程度であり, 今回測定した魚㽜油では大半が 滰油より高い值を示した。Fig. 2 に示したように全窒素 量が高い魚槒油ではペプチド態窒素量は高い值（重相関 係数：0.879）を示した。ペプチドの生成は, プロテア 一ゼによるタンパク質の分解とペプチダーゼによる遊離 アミノ酸生成とのバランスによって影響されると考えら れる。魚奨油が奨油に比べペプチド態窒素が高い值を示 すのは，滰油に比べ魚滰油ではその製造過程でのペプチ ダーゼ作用が小さいことが推察された。

アミノ態窒素とペプチド態窒素の相関性は0.590（重 相関係数）と低かった。このことは，ペプチドを生産す るプロテアーゼの作用挙動は魚㽜油間で類似しているが, ペプチダーゼの作用挙動が魚奨油間で異なるため遊離ア ミノ酸量に差異が生ずるものと考えられた。また，夕イ 産とベトナム産を比較するとアミノ態窒素とペプチド態 窒素は夕イ産のほうが低い值であった。これは食塩濃度 が高い夕イ産のほうが魚肉タンパク質の分解が低かった と考えられる。

\section{4. 遊離アミノ酸量}

遊離アミノ酸量の最高值はべトナム産V12の $22,507 \mathrm{mg}$, 最低值は日本産 $\mathrm{J} 1$ の $1,749 \mathrm{mg}$ であり, 国別の平均値を比 較すると日本産が7, $969 \mathrm{mg}$, タイ産が8, $276 \mathrm{mg}$, ベトナム 産が9, 578mgであった。PARKら ${ }^{20)}$ タイ, ベトナム, ミ ヤンマー, ラオス, 韓国拉よび日本の魚竩油では遊離ア ミノ酸量にバラッキがあることを報告している。遊離ア ミノ酸量をTable 2 に示した。

遊離アミノ酸ではグルタミン酸, スレオニン, アラニ ン，プロリン，バリンおよびアスパラギン酸などが主な アミノ酸で総遊離アミノ酸量の $50 \%$ 以上を占めていた。

一方, 魚肉タンパク質の主要構成アミノ酸の 1 つであ るアルギニン含量は試料間での変動が大きく, 最大值は

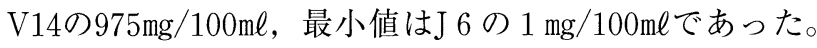
平均值を国別に比較すると夕イ $104 \mathrm{mg}$ ，ベトナム $89 \mathrm{mg}$,
日本 $402 \mathrm{mg}$ を示し，アルギニン量が $100 \mathrm{mg}$ 以下の試料は夕 イ産と日本産で 7 点, ベトナム産では21点, $10 \mathrm{mg}$ 以下で は夕イ産 2 , ベトナム産14, 日本産 5 であり, ベトナム 産魚槒油でアルギニン量の少ないものが多かった。太 田 ${ }^{6}$ は魚槒油の発酵過程を概和 2 つの段階に分けている。 第 1 段階は，魚タンパク質が金属プロテアーゼによって 高分子のペプチドに分解され，この段階ではアラニン， イソロイシン, アルギニン, アスパラギン酸などが多く 生成され，その際に細胞内のカテプシンBの働きにより セリンプロテアーゼが活性化され, 第 2 段階として, 活 性化されたセリンプロテアーゼをはじめアミノペプチダ 一ゼやカルボキシペプチダーゼが残存するペプチドを分 解し, 魚槒油の熟成を完成させると考えられると述べて いる。このことから，アルギニン量の小さな魚㽜油では ほかの魚酱油に比べ, 特に全公素量や総遊離アミノ酸量 が低いことから, 第 1 段階掞よび第 2 段階でのアルギニ ン生成に関与するペプチダーゼの作用量および作用性の 違いや，アルギニンデイミナーゼによるアルギニンから のアンモニア生成などの機作も推察され, 魚諲油製造に おける微生物の役割を考えるうえで大変興味深い。

\section{5. グルタミン酸含量}

魚槒油の主要な旨味成分であるグルタミン酸量の総遊 離アミノ酸量に対する割合は夕イ産魚㽜油では $10 \%$ 未満 2 点，10\%が 2 点， $11 \%$ が 2 点，12\%が 1 点， $29 \%$ が 1 点, ベトナム産は $10 \%$ 未満が 5 点, 10 20\%が 20 点, $20 \%$ 以上が 4 点, 日本産は $10 \%$ 未満が 16 点, $10 \sim 20 \%$ が 13 点 であり，国別平均では夕イ産 $12.5 \%$ ，ベトナム産 $13.7 \%$, 日本産 $9.9 \%$, 試料 66 点の平均值は約 $12 \%$ あった。

総遊離アミノ酸とグルタミン酸の関係をFig. 3 に示し た。グルタミン酸量 $2 \mathrm{~g}$ 付近を示す特徵的な試料が 6 点 （T1，V 5，V18，V21，V22，V27）あったが，それ ら 6 点を除いた試料はグルタミン酸量が多くなるに従っ て総遊離アミノ酸は正の相関がみられた（重相関係数： 0.838)。グルタミン酸量の平均は $976 \mathrm{mg}$ であったが, 最 高値と最低值の差は 13.5 倍もあった。今回の T $1, \mathrm{~V} 5$, $\mathrm{V} 18 ， \mathrm{~V} 21 ， \mathrm{~V} 22 ， \mathrm{~V} 27$ のううにグルタミン酸量が $2 \mathrm{~g}$ 付 近を示す試料 6 点はグルタミン酸の割合が約20〜30\%を 占め突出していた。これは魚肉たんぱく質中のグルタミ ン酸残基量（ $9 \sim 17 \%)$ 加も考えにくい数值である。 東南アジアでは魚槒油の未分解の残渣に塩水を加えて熟 成を継続し，魚滰油を製造することが行われ，この操作 が数回に及ぶことがある。このように調製された魚竩油 では総窒素量が低くなるため, グルタミン酸ナトリウム を加えたり，ほかのアミノ酸を加えていることがあると の報告がある ${ }^{71,17)}$ 。のことから，これらの魚㽜油には グルタミン酸を添加した可能性が考えられた。

\section{要 約}

タイ産，ベトナム産抢よび日本産の魚槒油66種を用い てそれらの化学組成を比較した。その結果, 魚槒油の性 
Table 2 Free amino acid contents of fish sauce

$\mathrm{mg} / 100 \mathrm{~m} \ell$

\begin{tabular}{|c|c|c|c|c|c|c|c|c|c|c|c|c|c|c|c|c|c|c|c|}
\hline $\begin{array}{c}\text { Sample } \\
\text { No. }\end{array}$ & Asp & Glu & H-Pro & Ser & Gly & His & Thr & Ala & Arg & Pro & Val & Cys & Met & Ile & Leu & Phe & Lys & Tyr & Total \\
\hline T 1 & 234 & 1472 & 4 & 150 & 129 & 147 & 362 & 314 & 27 & 151 & 305 & 103 & 157 & 330 & 551 & 241 & 323 & 64 & 5063 \\
\hline $\mathrm{T} 2$ & 310 & 434 & 18 & 241 & 235 & 210 & 464 & 381 & 93 & 272 & 415 & 98 & 173 & 396 & 601 & 338 & 397 & 72 & 5149 \\
\hline T 3 & 712 & 1036 & 44 & 532 & 555 & 367 & 995 & 787 & 4 & 700 & 769 & 106 & 131 & 468 & 514 & 550 & 676 & 69 & 9014 \\
\hline T 4 & 575 & 861 & 27 & 402 & 425 & 296 & 803 & 676 & 5 & 418 & 653 & 162 & 112 & 387 & 586 & 475 & 600 & 71 & 7533 \\
\hline T 5 & 973 & 1284 & 90 & 890 & 896 & 492 & 1312 & 1146 & 450 & 1421 & 1064 & 124 & 143 & 508 & 467 & 772 & 848 & 78 & 12958 \\
\hline T 6 & 767 & 759 & 56 & 423 & 315 & 736 & 585 & 464 & 97 & 630 & 474 & 179 & 485 & 524 & 588 & 810 & 748 & 155 & 8795 \\
\hline T 7 & 768 & 1109 & 53 & 601 & 535 & 627 & 1101 & 696 & 69 & 683 & 742 & 181 & 138 & 461 & 477 & 537 & 583 & 79 & 9442 \\
\hline T 8 & 711 & 787 & 61 & 366 & 295 & 602 & 590 & 494 & 84 & 453 & 462 & 180 & 438 & 519 & 605 & 734 & 734 & 137 & 8253 \\
\hline Mean & 631 & 968 & 44 & 451 & 423 & 435 & 776 & 620 & 104 & 591 & 611 & 141 & 222 & 449 & 549 & 557 & 614 & 91 & 8276 \\
\hline V 1 & 693 & 1433 & 39 & 453 & 552 & 375 & 1125 & 747 & 7 & 520 & 719 & 227 & 220 & 437 & 453 & 537 & 643 & 50 & 9230 \\
\hline $\mathrm{V} \quad 2$ & 1127 & 1718 & 84 & 1072 & 914 & 928 & 1845 & 1089 & 239 & 1622 & 1107 & 237 & 214 & 490 & 439 & 813 & 703 & 80 & 14721 \\
\hline V 3 & 1088 & 1546 & 86 & 1011 & 860 & 936 & 1735 & 1080 & 270 & 1632 & 1125 & 367 & 230 & 516 & 366 & 906 & 711 & 74 & 14538 \\
\hline V 4 & 1023 & 1312 & 66 & 844 & 781 & 742 & 1420 & 1017 & 348 & 1226 & 966 & 175 & 179 & 469 & 452 & 704 & 685 & 68 & 12478 \\
\hline V 5 & 604 & 1825 & 37 & 323 & 559 & 265 & 1007 & 758 & 6 & 396 & 695 & 165 & 142 & 452 & 437 & 445 & 532 & 55 & 8702 \\
\hline V 6 & 741 & 894 & 47 & 477 & 334 & 719 & 760 & 453 & 204 & 952 & 495 & 87 & 397 & 434 & 411 & 871 & 74 & 181 & 8531 \\
\hline V 7 & 934 & 1415 & 53 & 269 & 927 & 420 & 1465 & 1515 & 8 & 1380 & 1098 & 377 & 290 & 514 & 452 & 935 & 731 & 95 & 12878 \\
\hline V 8 & 697 & 1222 & 39 & 519 & 604 & 377 & 1404 & 1179 & 6 & 944 & 902 & 408 & 209 & 434 & 439 & 669 & 668 & 95 & 10815 \\
\hline V 9 & 542 & 964 & 75 & 460 & 573 & 311 & 1183 & 985 & 36 & 703 & 747 & 291 & 178 & 440 & 508 & 532 & 624 & 88 & 9240 \\
\hline $\mathrm{V} 10$ & 719 & 1249 & 31 & 541 & 600 & 348 & 1186 & 794 & 2 & 553 & 742 & 286 & 190 & 452 & 443 & 553 & 660 & 48 & 9398 \\
\hline V 11 & 459 & 757 & 134 & 413 & 560 & 277 & 1025 & 811 & 113 & 605 & 630 & 336 & 153 & 419 & 546 & 470 & 583 & 86 & 8377 \\
\hline V 12 & 1374 & 1897 & 196 & 1544 & 1488 & 1306 & 3235 & 2353 & 25 & 3355 & 1562 & 713 & 359 & 439 & 322 & 1290 & 920 & 129 & 22507 \\
\hline V 13 & 357 & 609 & 18 & 43 & 241 & 32 & 340 & 566 & 2 & 201 & 429 & 25 & 100 & 353 & 484 & 312 & 329 & 9 & 4492 \\
\hline V 14 & 890 & 1117 & 74 & 927 & 651 & 763 & 1522 & 912 & 975 & 1225 & 977 & 400 & 251 & 456 & 440 & 700 & 863 & 82 & 13225 \\
\hline $\mathrm{V} 15$ & 1118 & 1396 & 81 & 1132 & 869 & 924 & 1882 & 1097 & 166 & 1714 & 1140 & 305 & 196 & 517 & 452 & 872 & 853 & 44 & 14758 \\
\hline $\mathrm{V} 16$ & 690 & 1347 & 38 & 329 & 647 & 228 & 1258 & 1244 & 8 & 900 & 905 & 373 & 239 & 439 & 432 & 695 & 606 & 8 & 10478 \\
\hline V 17 & 661 & 1089 & 48 & 307 & 693 & 289 & 1248 & 1247 & 4 & 1029 & 928 & 548 & 251 & 425 & 409 & 786 & 755 & 109 & 10825 \\
\hline V 18 & 653 & 1745 & 25 & 409 & 513 & 324 & 936 & 691 & 9 & 462 & 694 & 183 & 226 & 459 & 486 & 522 & 596 & 49 & 8980 \\
\hline V 19 & 343 & 639 & 60 & 158 & 419 & 109 & 655 & 727 & 30 & 305 & & 190 & 134 & 390 & 531 & & 424 & 0 & 6043 \\
\hline $\mathrm{V} 20$ & 826 & 931 & 60 & 667 & 649 & 484 & 1178 & 915 & 116 & 951 & 858 & 197 & 169 & 413 & 401 & 592 & 782 & 62 & 10250 \\
\hline $\mathrm{V} 21$ & 343 & 1769 & 18 & 147 & 234 & 145 & 443 & 409 & 2 & 142 & 389 & 49 & 121 & 377 & 559 & 269 & 429 & 41 & 5885 \\
\hline $\mathrm{V} 22$ & 360 & 1890 & 18 & 196 & 253 & 165 & 608 & 451 & 6 & 215 & 320 & 273 & 143 & 369 & 546 & 305 & 379 & 8 & 547 \\
\hline $\mathrm{V} 23$ & 270 & 609 & 7 & 35 & 260 & 60 & 726 & 556 & 74 & 94 & 443 & 29 & 102 & 449 & 689 & 397 & 509 & 52 & 5361 \\
\hline $\mathrm{V} 24$ & 430 & 753 & 55 & 195 & 458 & 147 & 779 & 817 & 21 & 404 & 584 & 229 & 146 & 416 & 526 & 426 & 456 & 76 & 6916 \\
\hline $\mathrm{V} 25$ & 253 & 591 & 6 & 34 & 270 & 56 & 744 & 548 & 73 & 91 & 443 & 93 & 110 & 454 & 686 & 406 & 471 & 6 & 5386 \\
\hline $\mathrm{V} 26$ & 200 & 768 & 15 & 33 & 351 & 41 & 361 & 652 & 3 & 119 & 455 & 70 & 50 & 461 & 636 & 358 & 259 & 6 & 4900 \\
\hline V 27 & 647 & 2106 & 45 & 530 & 543 & 360 & 1051 & 683 & 3 & 596 & 685 & 219 & 189 & 398 & 392 & 494 & 646 & 54 & 9641 \\
\hline $\mathrm{V} 28$ & 573 & 1135 & 11 & 17 & 896 & 60 & 1230 & 1110 & 6 & 718 & 790 & 11 & 95 & 604 & 652 & 752 & 597 & 53 & 9309 \\
\hline V 29 & 176 & 606 & 20 & 69 & 218 & 39 & 228 & 450 & 21 & 94 & 262 & 23 & 13 & 249 & 385 & 194 & 255 & 46 & 3348 \\
\hline Mean & 647 & 1233 & 51 & 455 & 593 & 375 & 1139 & 903 & 89 & 785 & 754 & 247 & 177 & 440 & 484 & 582 & 596 & 68 & 9578 \\
\hline $\begin{array}{ll}\mathrm{J} & 1\end{array}$ & 160 & 156 & 3 & 84 & 83 & 75 & 185 & 131 & 79 & 64 & 100 & 51 & 37 & 90 & 152 & 78 & 165 & 55 & 1749 \\
\hline J 2 & 436 & 676 & 39 & 575 & 362 & 193 & 667 & 455 & 705 & 392 & 466 & 72 & 224 & 408 & 593 & 335 & 537 & 76 & 7211 \\
\hline J 3 & 326 & 653 & 31 & 723 & 347 & 205 & 655 & 483 & 755 & 413 & 478 & 174 & 227 & 423 & 632 & 355 & 586 & 64 & 7530 \\
\hline J 4 & 362 & 585 & 50 & 403 & 309 & 166 & 511 & 504 & 350 & 379 & 426 & 230 & 176 & 340 & 527 & 426 & 554 & 57 & 6357 \\
\hline J 5 & 544 & 866 & 18 & 41 & 345 & 48 & 452 & 562 & 3 & 284 & 439 & 38 & 35 & 343 & 612 & 270 & 312 & 44 & 5258 \\
\hline J 6 & 254 & 446 & 14 & 15 & 145 & 25 & 281 & 353 & 1 & 97 & 221 & 23 & 30 & 336 & 501 & 177 & 278 & 35 & 3232 \\
\hline J 7 & 571 & 859 & 26 & 298 & 324 & 53 & 736 & 519 & 420 & 286 & 437 & 250 & 73 & 419 & 644 & 251 & 134 & 59 & 6356 \\
\hline J 8 & 658 & 917 & 45 & 519 & 454 & 366 & 948 & 599 & 201 & 463 & 587 & 116 & 158 & 504 & 659 & 377 & 652 & 35 & 8258 \\
\hline J 9 & 546 & 751 & 35 & 320 & 372 & 663 & 729 & 504 & 140 & 360 & 483 & 64 & 89 & 463 & 672 & 289 & 496 & 42 & 7018 \\
\hline J 10 & 500 & 679 & 29 & 450 & 287 & 353 & 782 & 450 & 412 & 256 & 429 & 274 & 111 & 452 & 588 & 258 & 576 & 41 & 6928 \\
\hline J 11 & 529 & 685 & 40 & 387 & 413 & 138 & 666 & 418 & 435 & 302 & 379 & 19 & 46 & 323 & 438 & 141 & 400 & 34 & 5792 \\
\hline J 12 & 542 & 691 & 43 & 385 & 411 & 132 & 659 & 426 & 428 & 302 & 372 & 18 & 56 & 313 & 425 & 138 & 396 & 36 & 5773 \\
\hline J 13 & 634 & 805 & 65 & 698 & 644 & 713 & 1108 & 631 & 537 & 613 & 674 & 145 & 185 & 515 & 582 & 427 & 721 & 9 & 9754 \\
\hline J 14 & 686 & 857 & 67 & 708 & 688 & 800 & 1115 & 643 & 511 & 652 & 711 & 136 & 198 & 539 & 603 & 555 & 568 & 67 & 10105 \\
\hline J 15 & 701 & 874 & 64 & 710 & 650 & 818 & 959 & 673 & 783 & 682 & 696 & 165 & 185 & 521 & 574 & 446 & 651 & 49 & 10200 \\
\hline J 16 & 751 & 857 & 61 & 660 & 545 & 543 & 1287 & 728 & 513 & 871 & 675 & 80 & 179 & 449 & 522 & 462 & 757 & 49 & 9990 \\
\hline J 17 & 705 & 808 & 46 & 639 & 507 & 517 & 1254 & 678 & 505 & 808 & 626 & 95 & 193 & 425 & 495 & 417 & 704 & 50 & 9472 \\
\hline J 18 & 284 & 402 & 12 & 150 & 132 & 135 & 256 & 230 & 119 & 102 & 121 & 30 & 23 & 90 & 152 & 72 & 225 & 25 & 2561 \\
\hline J 19 & 577 & 694 & 91 & 560 & 625 & 368 & 904 & 581 & 674 & 588 & 484 & 18 & 90 & 386 & 554 & 219 & 543 & 52 & 8007 \\
\hline J 20 & 482 & 761 & 30 & 99 & 367 & 240 & 241 & 726 & 15 & 272 & 524 & 95 & 54 & 460 & 615 & 359 & 492 & 37 & 5869 \\
\hline J 21 & 837 & 725 & 77 & 704 & 670 & 285 & 1759 & 602 & 515 & 1058 & 619 & 33 & 220 & 496 & 529 & 586 & 642 & 87 & 10443 \\
\hline J 22 & 785 & 673 & 62 & 676 & 582 & 260 & 1712 & 562 & 564 & 948 & 602 & 45 & 176 & 504 & 550 & 624 & 622 & 115 & 10061 \\
\hline J 23 & 801 & 680 & 69 & 650 & 564 & 213 & 1511 & 568 & 541 & 872 & 549 & 40 & 214 & 483 & 558 & 502 & 675 & 93 & 9582 \\
\hline $\mathrm{J} 24$ & 55 & 865 & 63 & 641 & 634 & 193 & 1675 & 1317 & 588 & 1016 & 604 & 27 & 129 & 417 & 430 & 565 & 720 & 100 & 10040 \\
\hline J 25 & 341 & 831 & 58 & 33 & 661 & 61 & 978 & 1393 & 1 & 974 & 494 & 29 & 161 & 392 & 404 & 587 & 678 & 11 & 8087 \\
\hline J 26 & 64 & 871 & 64 & 29 & 679 & 196 & 1697 & 1355 & 4 & 1004 & 600 & 24 & 173 & 388 & 381 & 612 & 663 & 75 & 8878 \\
\hline J 27 & 1017 & 941 & 116 & 1082 & 969 & 1079 & 2661 & 740 & 923 & 1767 & 796 & 28 & 238 & 474 & 425 & 734 & 740 & 118 & 14848 \\
\hline J 28 & 1050 & 974 & 123 & 1057 & 994 & 406 & 2626 & 735 & 926 & 1900 & 825 & 19 & 215 & 487 & 426 & 759 & 663 & 110 & 14292 \\
\hline J 29 & 44 & 740 & 47 & 23 & 532 & 158 & 1321 & 1234 & 1 & 742 & 486 & 39 & 135 & 337 & 359 & 535 & 637 & 82 & 7451 \\
\hline Mean & 526 & 735 & 51 & 459 & 493 & 324 & 1046 & 648 & 402 & 637 & 514 & 82 & 139 & 406 & 503 & 399 & 544 & 61 & 7969 \\
\hline
\end{tabular}

$\mathrm{T}$ : Made in Thailand $\mathrm{V}$ : Made in Vietnam $\mathrm{J}$ : Made in Japan 


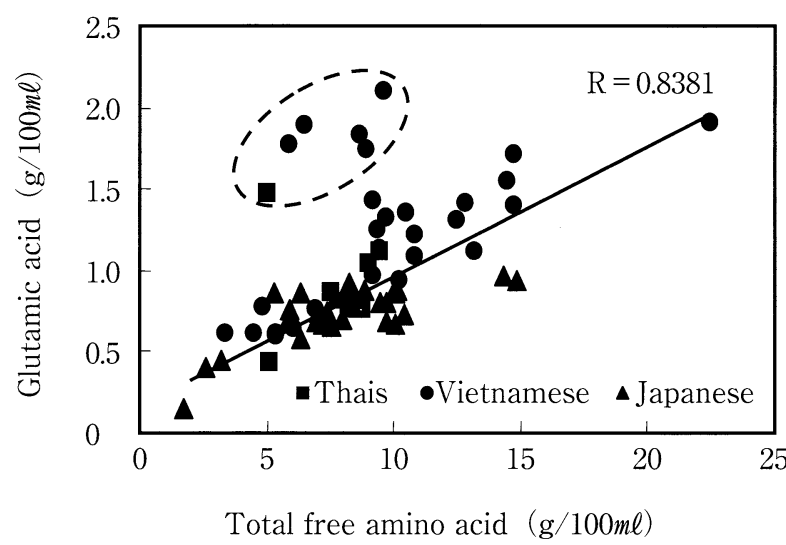

Fig. 3 Correlations between total amino acid and Glutamic acid of fish sauce

Samples in the circle were considered to be added glutamic acid because of their high glutamic acid content in total free amino acid

状が非常に多様であることを確認した。食塩濃度は14〜

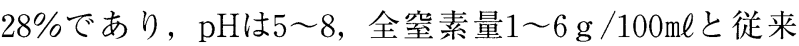
の報告と比べ，これらの值の範囲が広かった。また，全 窒素量が高い魚奨油はペプチド態窒素量が多かった。生 体への機能が興味深いペプチドの含量は全空素に対し全 魚奨油の平均は $32 \%$ あった。国別では日本産よりも夕 イ産，ベトナム産が高く，亜熱带から熱带気候に位置す るタイやベトナムは日本より高温で熟成させるため，プ ロテアーゼによる魚肉タンパク質の分解が高かったと考 えられた。総遊離アミノ酸と代表的な旨味成分であるグ ルタミン酸との関係では総遊離アミノ酸量が多くなるに 従ってグルタミン酸量は高い值を示し，その割合は平均 で12\%であった。一方，グルタミン酸の割合が $20 〜 30 \%$ と魚肉タンパク質の同組成值よりも高い值を示すものも あり，これらはグルタミン酸を添加している可能性が考 えられた。

\section{文献}

1 ）柳田藤治：古くて新しい調味料 “魚㽜”, 食品工 業，39，16〜23（1996）

2 ）川㟝賢一：新しい魚槒油の開発と利用法, 調理食品 と技術，11，115～124（2005）

3 ）藤井建夫：魚介類の保蔵から生まれた発酵食品, 日 食品保蔵誌，25，245～252（1999）

4 ) Park, J., Funumoto, Y., Fujita, E., Tanaka, T., Washio, T., Otsuka, S., Shimizu, T., Watanabe, K. and ABE, H.: Chemical Composition of Fish Sauce Produced in Southeast and East Asian Countries, J. Food Comp Anal, 14, 113 125 (2001)

5 ) 阿部宏喜：魚奨油の味, New Food Industry，45，39 $\sim 45$ (2003)

6）太田静行：魚奨油の知識（幸書房, 東京), p. 23, p. 86 (1996)
7 ) 鍛治義延：発酵調味料「槒（じゃん）シリーズ」の 開発，醸協，90，81８18（1995）

8 ）西場洋一：生態調節機能に着目した加工食品の開発 に関する動向，農林水産研究文献解題，30，291～296 (2004)

9 ) 田村吉隆：乳業における機能性食品素材と応用, 月 刊フードケミカル，12，19〜23（2003）

10) Окамото (Kainuma), A., Matsumoto, E., Iwashita, A., Yasuhara, T., Kawamura, Y., Koizumi, Y. and Yanagida, F. : Angiotensin I-Converting Enzyme Inhibitory Action of Fish Sauce, Food Sci. Technol., Int., 1, 101 106 (1995)

11) Ichimura, T., Hu, J., Aita, D. Q. and Maruyama, S. : Angiotensin I -Converting Enzyme Inhibitory Activity and Insulin Secretion Stimulative Activity of Fermented Fish Sauce, JOURNAL OF BIOSCIENCE AND BIOENGINEERING, 96, 496 499 (2003)

12) Jung, W. K., Rajapakse, N. and KIm, S. K. : Antioxidative activity of a low molecular weight peptide derived from the sauce of fermented blue mussel, Mytilus edulis, Eur. Food Res. Technol., 220, 535 539（2005）

13）日本奨油研究所編集：しょうゆ試験法（日本酱油研 究所，東京)，pp. 19～20（1985）

14）日本生化学会編集：新生化学実験講座 1 タンパク 質 II 一次構造（東京化学同仁，東京）, pp. 40 50 (1990)

15) Gasaluck, P., Yokohama, K., Kimura, T. and Sugahara, I. : Some Chemical and Microbiological Properties of Thai Fish Sauce and Paste, $J$. Antibact. Antifung. Agents, 24, 385 390 (1996)

16) Wood, B. J. B. : Microbiology of fermented foods, V.2 (Elsevier Applied Science Publishers, New York), p. 5, pp. 20 22 (1985)

17）三枝弘育：夕イ，ベトナム，カンボジアおよび日本 で製造された魚㽜油の成分比較, 東京都立食品技術七 ンター研究報告， 9，33〜43（2000）

18）谷口（山田）亜樹子 - 佐藤広顕 · 三森一司 - 菊池修 平・高野克己：ブナ化したシロサケOncorhynchusketa を用いた魚槒油の製造における各種プロテアーゼ製剤 の影響，日食保蔵誌，29，17～23（2003）

19）道畠俊英 - 佐渡康夫 - 矢野俊博 - 榎本俊樹 : 速醸法 によるイシル（魚酱油）の調製とその醉造過程におけ る成分の消長，食工誌，47，369～377（2000）

20) Park, J., Fukumoto, Y., Fujita, E., Tanaka, T., Washio, T., Otsuka, S., Shimizu, T., Watanabe, K. and ABE, H.: Chemical Composition of Fish Sauce Produced in Southeast and East Asian Countries, J. Food Comp Anal, 14, 113 125（2001）

(平成20年 6 月 4 日受付，平成 20 年 8 月 25 日受理) 